\title{
Essential Oil Composition, Antioxidant and Antibacterial Activities of Nutmeg (Myristica fragrans Houtt.) From Garut West Java
}

\author{
Diki P. Wibowo*, Yessi Febriani, Hesti Riasari, Diah L. Aulifa \\ Department of Pharmaceutical Biology, Indonesia School of Pharmacy, Bandung, Indonesia
}

Submitted 09 March 2018; Revised 25 June 2018; Accepted 09 July 2018, Published 01 October 2018

*Corresponding author: diki1310@gmail.com

\begin{abstract}
West Java is rich in essential oil-producing plants, essential oils known to be responsible for some pharmacological activities among its antioxidant and antimicrobial. This research aims to know antimicrobial, antioxidant activity and identify the components of a compound essential oil of nutmeg (Myristica fragrans Houtt.). Components chemistry identified with GC-MS (Gas ChromatographyMass pectrometer). Antioxidant activity measured by using the DPPH method (2 2-diphenyl-1picrylhydrazyl) at $\lambda 516 \mathrm{~nm}$ wavelength absorbance. Antimicrobial activity determined Minimum Inhibitory Concentrations (MIC) and Minimum Bactericidal Concentrations (MBC) using microdilution method. The result of GC-MS showed the highest component on nutmeg containing $22.22 \%$ myristicin. The antioxidant test showed nutmeg had $\mathrm{IC}_{50}$ at 3,16\%, essential oil showed antibacterial activity against Gram positive and Gram negative bacteria. Minimum inhibitory concentrations of essential oils range from $0.313 \%$ to $10 \%$. The content of essential oils of nutmeg plants that grow in the area of West Java Garut can be used to overcome the problems of antioxidants and antimicrobial.
\end{abstract}

Keywords: Antioxidant, antibacterial, chemical composition, pala (Myristica fragrans Houtt).

\section{Komposisi Minyak Atsiri, Uji Aktivitas Antioksidan Dan Antibakteri Biji Pala (Myristica fragrans Houtt.) Dari Garut Jawa barat}

\begin{abstract}
Abstrak
Jawa Barat kaya akan keaneragaman hayati penghasil minyak atsiri, yang diketahui bertanggung jawab terhadap beberapa akivitas farmakologi diantaranya antioksidan dan antimikroba. Penelitian ini bertujuan untuk mengetahui aktivitas antioksidan, antimikroba dan mengidentifikasi komponen senyawa minyak atsiri Pala (Myristica fragrans Houtt). Minyak atsiri di isolasi dengan metode destilasi uap air dan komponen kimianya diidentifikasi dengan KG-SM (Kromatgrafi Gas - Spektrometri Massa). Antioksidan diukur dengan menggunakan metode DPPH (2, 2-difenil-1-pikrilhidrazil) dengan absorbansi pada panjang gelombang $\lambda 516 \mathrm{~nm}$ dan aktivitas antimikroba dilakukan dengan menentukan Konsentrasi Hambat Minimum (KHM) dan Konsentrasi Bunuh Minimum (KBM) dengan menggunakan metode mikrodilusi. Hasil KG-SM menunjukan komponen tertinggi pada pala mengandung Miristisin 22, 22 \%. Uji antioksidan menunjukan pala memiliki nilai $\mathrm{IC}_{50}$ sebesar 3,16\%, minyak esensial menunjukkan aktivitas antibakteri terhadap bakteri Gram positif dan Gram negatif. Konsentrasi hambat minimum dari minyak esensial berkisar antara $0,313 \%$ sampai $10 \%$. Kandungan minyak atsiri tanaman pala yang tumbuh di daerah Garut Jawa Barat dapat digunakan untuk mengatasi permasalahan antioksidan dan antimikroba.
\end{abstract}

Kata Kunci: Antioksidan, antibakteri, komposisi kimia, pala (Myristica fragrans Houtt.). 


\section{Pendahuluan}

Myristica fragrans Houtt. dari suku Myristicaceae, yang dikenal sebagai Pala di Indonesia telah digunakan secara tradisional untuk rempah-rempah dan obat-obatan untuk meningkatkan sistim imun dan radioprotektif ${ }^{1}$, antidiabetes ${ }^{2}$, antikonvulsan, antimoluska ${ }^{3}$, hepatoprotektif ${ }^{4}$, antikarsinogen $^{5}$, aprodisiak ${ }^{6}$, antidepresan ${ }^{7}$, antioksidan $^{8,9}$, antimikroba. ${ }^{10,11,12}$

Konstituen utama Pala (M. fragrans Houtt) telah ditemukan sebagai turunan alkil benzena (miristisin, elemisin, safrol dll.), Terpen, $\alpha$-pinene, $\beta$-pinene, asam myristat dan trimiristin. Pala mengandung sekitar $10 \%$ minyak esensial, yang sebagian besar terdiri dari hidrokarbon terpen (sabinena dan pinena), kampen, peptida, pellandren terpinen, limonen, mirsen, berkisar 60 sampai $80 \%$ ), turunan terpen (linalool, geraniol, terpineol, 5 sampai 15\%) dan turunan fenilpropanoid (miristisin, elemisin, safrol, dan eugenol, bersama-sama 15 sampai $20 \%)^{12}$

Tujuan dari penelitian ini adalah untuk mengetahui aktivitas antioksidan, antimikroba dan mengidentifikasi komponen senyawa minyak atsiri buah pala, untuk kemungkinan pemanfaatannya sebagai obat-obatan, pengawet makanan, seperti nutraceuticals dan aplikasi terapeutik.

\section{Metode}

\subsection{Bahan tumbuhan}

Buah Pala (M. fragrans Houtt) dikumpulkan dari daerah Pamalayan Kecamatan Cisewu, Garut. Destilasi minyak atsiri dilakukan di Balai Penelitian Tanaman Obat dan Tanaman Aromatik (BALITTRO), Manoko, Lembang, Jawa Barat. Spesies di identifikasi di Herbarium Jatinangor, Laboratorium Taksonomi Tumbuhan, Jurusan Biologi Universitas Padjadjaran dengan no specimen 123/HB/03/2017.

\subsection{Isolasi minyak atsiri}

Biji buah pala (M. fragrans Houtt) di isolasi menggunakan alat destilasi uap dan air selama 3 jam. Minyak atsiri yang dihasilkan kemudian disimpan pada suhu $4^{\circ} \mathrm{C}$ sampai digunakan untuk analisis.
2.3. Analisis kromatografi Gas Spektrometri massa (KG-SM)

Komposisi minyak atsiri ditentukan dengan menggunakan kromatografi gas Shimadzu GCMS-QP2010 Ultra. Suhu oven dimulai pada suhu $60^{\circ} \mathrm{C}$. Suhu injektor dan detektor masing-masing diatur $280^{\circ} \mathrm{C}$. Analisis dilakukan dengan menggunakan helium sebagai gas pembawa pada laju alir 1, $31 \mathrm{~mL} / \mathrm{menit}$. Aliran total 264, $7 \mathrm{~mL} /$ menit, tekanan $80,2 \mathrm{kPa}$, Kecepatan linear $41,7 \mathrm{~cm} /$ $\mathrm{sec}$, aliran Pureg 2,0 mL/menit dan rasio split 200. MS dilengkapi dengan sumber ion suhu $230^{\circ} \mathrm{C}$, waktu antar muka $250^{\circ} \mathrm{C}$, detektor mode gain mutlak dan detector mendapatkan $0,80 \mathrm{kV}$.

\subsection{Aktivitas Antioksidan (Peredaman radikal bebas DPPH)}

Metode yang digunakan untuk penentuan aktivitas antioksidan menggunakan metode peredaman radikal bebas DPPH. Pengenceran terhadap ekstrak metanol menghasilkan deret konsentrasi yang berbeda yang kemeudian masing-masing konsentrasi dicampur dengan volume larutan metanol DPPH dengan volume yang sama $(0,004 \%$ $\mathrm{b} / \mathrm{v})$.

Setelah 30 menit masa inkubasi pada suhu kamar, absorbansi dibaca pada panjang gelombang $\lambda 517 \mathrm{~nm}$. Penghambatan radikal bebas oleh DPPH dalam persen (P \%) dihitung dengan cara sebagai berikut:

$\%$ Penghambatan $=(\mathrm{AC}-\mathrm{AS} / \mathrm{AC}) \times 100$

Dimana AC adalah absorbansi reaksi kontrol (mengandung volume larutan DPPH dan metanol yang sama tanpa sampel), dan AS adalah absorbansi sampel (minyak esensial dan standar).

\subsection{Aktivitas antimikroba}

Aktivitas antibakteri minyak atsiri dievaluasi dengan menggunakan metode mikrodilusi dan diuji terhadap 6 bakteri.

Empat bakteri gram positif yaitu Staphylococcus aureus ATCC6538, Bacillus subtilis ATCC6633, Bacillus cereus ATCC11778 dan MRSA. Dua bakteri gram 
negatif yaitu Pseudomonas aeruginosa ATCC9027, dan Escherichia coli ATCC8939. Bakteri ini diperoleh dari laboratorium mikrobiologi Institut Teknologi Bandung, Indonesia, dan semua strain dikultur pada suhu $37^{\circ} \mathrm{C}$ pada media Mueller-Hinton Agar.

\subsection{Bahan}

Bahan yang di gunakan adalah buah Pala (M. fragrans Houtt), aquadest, Vitamin $\mathrm{C}$, DPPH, metanol pro analisis, MuellerHilton Broth (MHB), Mueller-Hilton Agar (MHA).

\section{Hasil}

Kromatogram hasil analisis KG-SM menunjukan kandungan minyak atsiri dari pala, hasil dapat dilihat pada Gambar 1.

\subsection{Komposisi Minyak Atsiri}

Hasil uji komposisi minyak atsiri hasil KG-SM Pala (Myristica fragrans) yang dihasilkan dengan cara destilasi uap dan air ditunjukan pada Tabel 1.

\subsection{Aktivitas Antioksidan}

Hasil uji aktivitas antioksidan dihitung berdasarkan \% Inhibisi,yang kemudian dibuat regresi linier untuk menghitung $\mathrm{IC}_{50}$. Data dapat dilihat pada Tabel 2 dan Gambar 2.
Hasil perhitungan persamaan kurva regresi linier perhitungan antioksidan dengan metode peredaman DPPH dapat dilihat pada Gambar 2.

\subsection{Aktivitas Antimikroba}

Hasil uji aktivitas antimikroba dengan menentukan Kadar Hambat Minimum (KHM) dan Kadar Bunuh Minimum (KBM) menggunakan metode mikrodilusi dapat dilihat pada Tabel 3 .

\section{Pembahasan}

Sebanyak 60 komponen diidentifikasi dari minyak atsiri pala (M. fragrans Houtt). Jumlah seluruhnya komposisi kimia minyak atsiri di berikan pada Gambar 1 .

Konstituen utama minyak atsiri Pala adalah miristicin (22,22\%), 4-terpineol $(14,45 \%)$, safrol $(6,94 \%)$, sabinen $(5,87 \%)$, $\alpha$-pinene $\quad(5,45 \%), \quad \delta$-limonen $\quad(3, \quad 88 \%)$ dan komponen minor lainnya (Tabel 1). Minyak atsiri adalah metabolit sekunder tanaman. Profil kandungan kimia minyak atsiri cenderung menunjukkan sifat kimia yang berbeda, yang disebabkan oleh faktor ekologi, kondisi geografis, umur dan waktu panen tanaman, perbedaan sifat kimiawi akan terjadi memiliki efek pada aktivitas biologis untuk menghasilkan seragam aktivitas

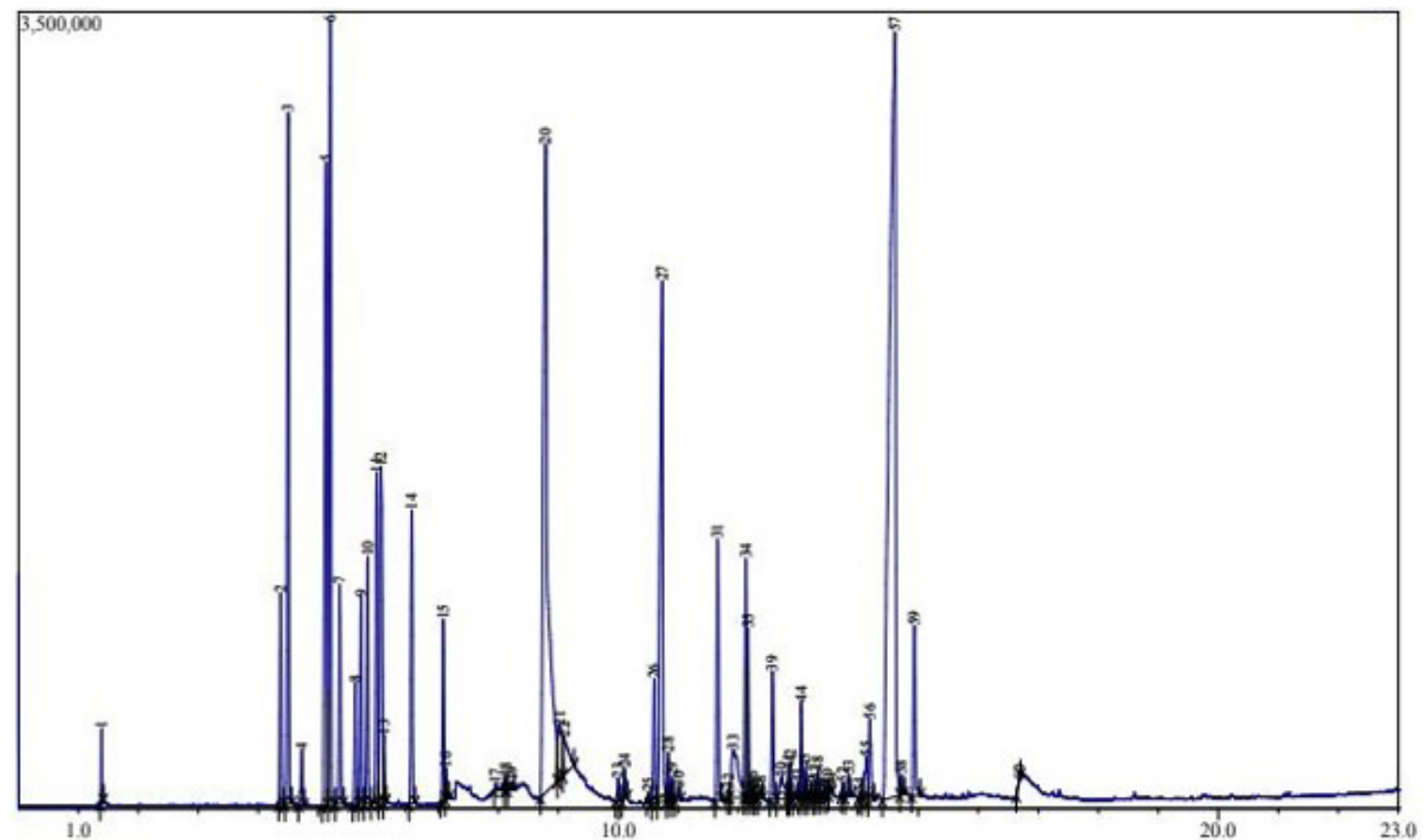

Gambar 1 Profil Kromatografi KG-SM dari Myristica fragrans 
Tabel 1 Hasil Identifikasi minyak atsiri dari buah Pala (M. fragrans) dengan menggunakan KG-SM

\begin{tabular}{|c|c|c|}
\hline No & Komponen Kimia & Pala $(\%)$ \\
\hline 1 & Etanol & 0,31 \\
\hline 2 & $\alpha$. -Thujena & 1,37 \\
\hline 3 & $\alpha$-Pinena & 5,45 \\
\hline 4 & Kamfen & 0,42 \\
\hline 5 & Sabinena & 6,98 \\
\hline 6 & $2-\beta$-Pinena & 7,1 \\
\hline 7 & $\beta$-Mirsena & 1,43 \\
\hline 8 & 1-Felandren & 0,82 \\
\hline 9 & $\delta 3$-Karena & 1,39 \\
\hline 10 & $\alpha$-Terpinena & 1,75 \\
\hline 11 & p-Simena & 2,62 \\
\hline 12 & $\delta$-Limonena & 3,88 \\
\hline 13 & 1,8-Sineol & 0,34 \\
\hline 14 & Gamma.-Terpinena & 2,24 \\
\hline 15 & $\alpha$-Terpinolen & 1,31 \\
\hline 16 & Benzene, 1-Isopropenil & 0,22 \\
\hline 17 & Siklobutena & 0,13 \\
\hline 18 & Epoksiterpinolen & 0,1 \\
\hline 19 & Sitronella & 0,07 \\
\hline 20 & 4-Terpineol & 14,45 \\
\hline 21 & 3-Sikloheksana-1-metanol, .alpha.,.alpha.,4-trimetil & 1,07 \\
\hline 22 & 3-Sikloheksana-1-metanol, .alpha.,.alpha.,4-trimetil & 0,91 \\
\hline 23 & Linaliil Asetat & 0,19 \\
\hline 24 & Piperitone & 0,26 \\
\hline 25 & $\beta$-Terpinil Asetat & 0,06 \\
\hline 26 & Endobornil Asetat & 0,96 \\
\hline 27 & Safrol & 6,94 \\
\hline 28 & 4-Terpinenil asetate & 0,39 \\
\hline 29 & Benzena, 1-metoksi-4-pentil & 0,18 \\
\hline 30 & Ascaridole & 0,12 \\
\hline 31 & $\alpha$ - Terpinenil Asetat & 2,15 \\
\hline 32 & Neril Asetat & 0,07 \\
\hline 33 & 3-Allil-6-metoksipenol & 1,56 \\
\hline 34 & $\alpha .-$ Kubebena & 2,02 \\
\hline 35 & Geranil asetat & 1,14 \\
\hline 36 & $\beta$-Patchoulena & 0,09 \\
\hline 37 & Zingiberen & 0,04 \\
\hline 38 & $\beta$-Elemena & 0,08 \\
\hline 39 & Methil eugenol & 1,09 \\
\hline 40 & Vanillin & 0,5 \\
\hline 41 & 2-heksilfuran & 0,21 \\
\hline 42 & Bisiklo[5.2.0]Nonan, 2-Metilena-4,8,8-Trimetil-4-Vinil (CARYOPHYLLEN & 0,27 \\
\hline 43 & p-Metoksifenil glisidil eter & 0,18 \\
\hline 44 & $\alpha$. -Bergamotena & 0,73 \\
\hline 45 & a.-Guaina & 0,23 \\
\hline 46 & Neoallosimina & 0,06 \\
\hline 47 & Seysellena & 0,13 \\
\hline 48 & Farnesol & 0,19 \\
\hline
\end{tabular}


Tabel 1 (Lanjutan)

\begin{tabular}{|c|c|c|}
\hline 49 & a.-Humulena & 0,03 \\
\hline 50 & a.-Patchoulena & 0,08 \\
\hline 51 & gamma.-Gurjunena & 0,06 \\
\hline 52 & Naftalena & 0,09 \\
\hline 53 & Germakren-D & 0,17 \\
\hline 54 & Epi-Bisikloseskuifellandren & 0,1 \\
\hline 55 & Farnesen & 0,57 \\
\hline 56 & Cis-Kariofilen & 0,76 \\
\hline 57 & Miristisin & 22,22 \\
\hline 58 & a.-Bisabolen & 0,18 \\
\hline 59 & Elemisin & 1,49 \\
\hline 60 & Patkouli alkohol & 0,04 \\
\hline
\end{tabular}

biologis. Analisis komponen utama bisa dijadikan alternatif sebagai dasar penentuan kualitas minyak esensial.

Prinsip metode DPPH didasarkan pada reaksi penangkapan atom hidrogen oleh DPPH dari senyawa antioksidan, sehingga dihasilkan $\mathrm{IC}_{50}$ dimana nilai $\mathrm{IC}_{50}$ dinyatakan sangat kuat bila $<50 \mu \mathrm{g} / \mathrm{mL}, 50-100 \mu \mathrm{g} / \mathrm{mL}$ dinyatakan kuat, $101-150 \mu \mathrm{g} / \mathrm{mL}$ dinyatakan sedang dan dikatakan lemah bila nilai $\mathrm{IC}_{50}$ $>150 \mu \mathrm{g} / \mathrm{mL}^{13}$
Kapasitas antioksidan minyak atsiri pala dan komponen utamanya ditunjukan pada Gambar 2 dan Tabel 2. Minyak atsiri pala mempunyai $\mathrm{IC}_{50}$ pada konsentrasi 3,16 $\%$, hal ini menunjukan minyak atsiri pala mempunyai aktivitas antioksidan yang kuat.

Hasil pengujian aktivitas antibakteri menunjukan bahwa KHM dari minyak atsiri terhadap bakteri uji mempunyai nilai bervariasi antara 0,31\%-10\%. Bakteri uji merupakan bakteri patogen utama pada

Tabel 2 Hasil \% Inhibisi dan IC 50 berbagai konsentrasi minyak atsiri buah Pala

\begin{tabular}{cccc}
\hline Konsentrasi (\%) & Absorbansi & \% Penghambatan & $\mathrm{IC}_{50}$ \\
\hline 0,20 & 0,43 & 14,25 & \\
0,40 & 0,41 & 17,56 & \\
0,80 & 0,38 & 24,19 & 3,16 \\
1,60 & 0,33 & 35,26 & \\
3,20 & 0,26 & 48,71 & \\
6,40 & 0,08 & 86,93 & \\
\hline
\end{tabular}

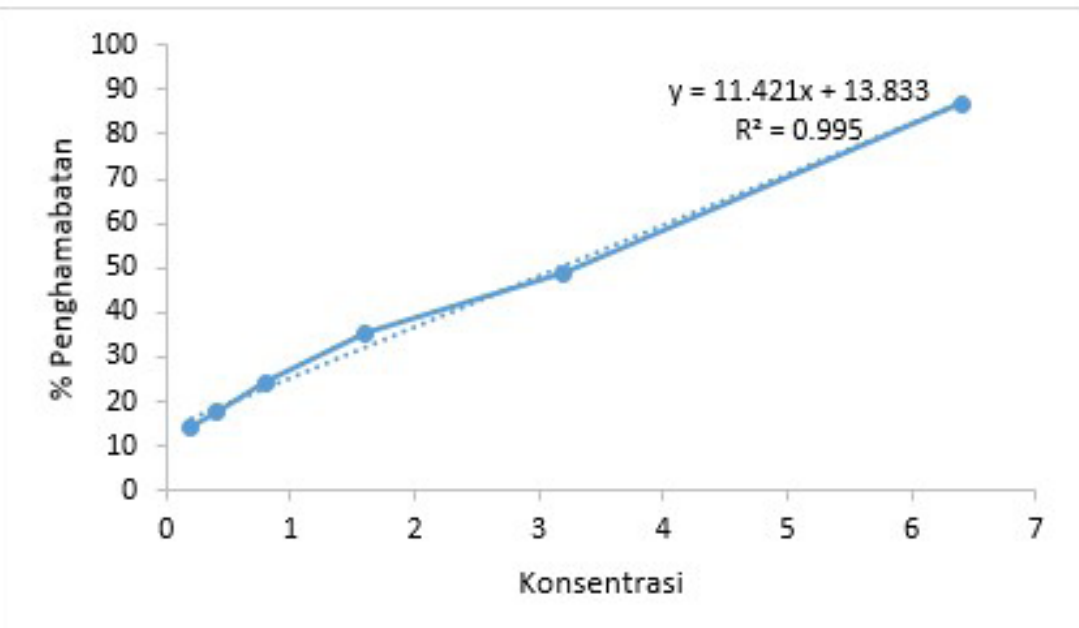

Gambar 2 Grafik persamaan regresi linier \% Inhibisi berbagai konsentrasi minyak atsirI 
Tabel 3 Kosentrasi Hambat Minimum (KHM) dan Konsentrasi Bunuh Maksimum (KBM) Minyak Atsiri Buah Pala

\begin{tabular}{cccccccc}
\hline Minyak Atsiri & Daya Hambat & E Coli & P aeruginosa & B cereus & B subtilis & S aureus & MRSA \\
\hline \multirow{2}{*}{ Pala } & KHM $(\% \mathrm{v} / \mathrm{v})$ & 2,5 & - & 0,313 & 10 & 0,625 & 2,5 \\
& KBM $(\% \mathrm{v} / \mathrm{v})$ & 10 & - & 5 & $>10$ & 10 & $>10$ \\
\hline
\end{tabular}

manusia yang dapat menyebabkan berbagai masalah kesehatan. Hampir semua orang akan pernah merasakan infeksi selama hidupnya, mulai dari infeksi yang cukup parah, keracunan makanan atau infeksi kulit ringan hingga infeksi yang mengancam jiwa. Pada penelitian ini menunjukkan bahwa minyak atsiri pala dapat digunakan digunakan untuk menangulangi penyakit infeksi yang di sebabkan bakteri $E$ coli, B cereus, $B$ subtilis, $S$ aureus dan MRSA.

\section{Simpulan}

Dari hasil penelitian yang diuraikan diketahui bahwa kandungan minyak atsiri tanaman pala yang tumbuh di daerah Garut Jawa Barat dapat digunakan untuk mengatasi permasalahan antioksidan dan antimikroba.

\section{Daftar Pustaka}

1. Checker R, Chatterjee S, Sharma D, Gupta S, Variyar P, Sharma A, et al. Immunomodulatory and radioprotective effects of lignans derived from fresh nutmeg mace (Myristica fragrans) in mammalian splenocytes. Int Immunopharmacol. 2008;8(5):661-9.

2. Somani RS, Singhai a K. Hypoglycaemic and antidiabetic activities of seeds of Myristica fragrans in normoglycaemic and alloxan-induced diabetic rats. Asian J Exp Sci. 2008;22(1):95-102.

3. Jaiswal P, Singh DK. Molluscicidal activity of nutmeg and mace (Myristica fragrans houtt.) against the vector snail lymnaea acuminata. J Herbs, Spices Med Plants. 2009;15(2):177-86.

4. Kareem MA, Gadhamsetty SK, Shaik AH, Prasad EM, Kodidhela LD. Protective effect of nutmeg aqueous extract against experimentally-induced hepatotoxicity and oxidative stress in rats. Journal of Ayurveda and Integrative Medicine.
2013;4(4):216-223.

5. Galhotra, Virat, Sofat, Anjali, Dua Harpreet; Rohila, Sushant. Anticariogenic And Cariostatic Potential Of Components Of Diet: A Review. Indian Journal of Dental Sciences . 2014 Supp (4): 079085 .

6. Agbogidi OM. and Azagbaekwe OP. health and nutritional benefits of nut meg (mystica fragrans houtt.): Sci. Agri. 2013;1(2):40-44.

7. Moinuddin G, Devi K, Kumar Khajuria D. Evaluation of the anti-depressant activity of Myristica fragrans (Nutmeg) in male rats. Avicenna J Phytomed. 2012; 2(2):72-78.

8. Gupta A, BAnsal V, Babu V, et al. Chemistry, antioxidant and antimicrobial potential of nutmeg (Myristica fragrans Houtt). J Gen Engine and Biotechnol. 2013;1(11):25-31.

9. C.A. Calliste, D. Kozlowski, J.L. Duroux, Y. Champavier, A.J. Chulia, P. Trouillas, A new antioxidant from wild nutmeg. Food Chem. 2010;3(118):489-496

10. El Malti J, Bourhim N, Amarouch H. Toxicity and antibacterial effect of mace of Myristica fragrans used in Moroccan gastronomy: Biochemical and histological impact. J Food Saf. 2008;28(3):422-41.

11. Cui H., Zhang X. Zhou H. Zhao C. Xiao Z, Lin L, and Li C., Antibacterial Properties of Nutmeg Oil in Pork. J Food Saf. 2015;3(35): 370-377.

12. Jaiswal P, Kumar P, Singh VK, Singh DK. Biological effects of Myristica fragrans. Annu Rev Biomed Sci. 2009;11(March):21-9.

13. Jun M, Fu HY, Hong J, Wang X,Yang CS, Ho CT. Comparison of antioxidant activities of isoflavones from kudzu root (Pueraria lobate ohwi). J of Food Science. 2006. 2117- 22. 